\title{
Responding to a Forest Catastrophe: The Emergence of New Governance Arrangements in Southern California
}

\author{
Brian Petersen $^{1}$ and Adam M. Wellstead ${ }^{2}$ \\ ${ }^{1}$ Environmental Studies, Western Michigan University, 1903 West Michigan Avenue, Kalamazoo, MI 49008, USA \\ ${ }^{2}$ Department of Social Sciences, Michigan Technological University, 1600 Townsend Street, Houghton, MI 49931, USA
}

Correspondence should be addressed to Brian Petersen; brian.petersen@wmich.edu

Received 5 November 2013; Accepted 16 January 2014; Published 20 February 2014

Academic Editors: J. F. Negrón, A. Santini, and B. Schirone

Copyright (C 2014 B. Petersen and A. M. Wellstead. This is an open access article distributed under the Creative Commons Attribution License, which permits unrestricted use, distribution, and reproduction in any medium, provided the original work is properly cited.

The San Bernardino National Forest in southern California experienced an unprecedented bark beetle outbreak in the early 2000 s. The outbreak, coupled with a looming threat of catastrophic wildfire, droughts, changing forest management priorities, and a legacy of poor forest management practices coalesced to create a challenge that existing institutions and management agencies could not address. In response, an interagency collaborative effort, the Mountain Area Taskforce (MAST), was initiated. Based on key informant interviews, this paper details how this new governance organization emerged and how it effectively addressed a landscape scale forest challenge. Forest governance analyses often focus attention on macroscales, overlooking the microlevel arrangements that set MAST apart from other responses to bark beetle outbreaks. Interagency collaboration has taken on greater importance in efforts to address forest management at landscape scales and this case study provides important insights into the challenges and opportunities of these new governance arrangements.

\section{Introduction}

In 2001, Southern California's forests experienced the largest bark beetle outbreak on record. The magnitude of the outbreak, which peaked between 2003 and 2004, led to unprecedented forest dieback, which dramatically altered the forest landscape and contributed to extensive socioeconomic consequences. Subsequent to the outbreak, devastating fires occurred across southern California in 2003. In the San Bernardino National Forest (SBNF) the "Old" and "Grand Prix" fires merged, burned 5,863 hectares of forest, destroyed thousands of homes, and cost more than $\$ 2$ billion in firefighting and property damage $[1,2]$. Another fire, in 2007, in the San Bernardino Mountains burned hundreds of more homes. The "Station Fire" in the Angeles National Forest just outside of Los Angeles in the fall of 2009 once again brought national attention to forest management issues in the region.

In this paper, we examine a systems-based collaborative effort, the Mountain Areas Safety Taskforce (MAST), that mobilized to address a forest health crisis in southern California's forests. We present two arguments about natural resource collaborative decision making. First, based on a three-level approach (Table 1), we argue that problems visible at a macrolevel (forest health crisis) require not only an examination of mesolevel governance arrangements but also the microfeatures of interagency collaborations such as MAST and the on-the-ground implementation of its programs. In this case, these microlevel arrangements contributed to an effective response to the crisis. We aim to illustrate how this effective response developed and how this example contributes towards a better understanding of how successful interagency collaboration can emerge. Bark beetle outbreaks posed significant challenges to land managers and policy makers across western North America. In southern California an integrated, collaborative response materialized that later served as a model for other areas facing similar challenges. This microlevel interagency collaboration sets this case apart from others, providing an opportunity to assess 
TABLE 1: A three-level approach to policy logic.

\begin{tabular}{llll}
\hline System level & Political actors & Policy-relevant aspects & Policy focus \\
\hline $\begin{array}{l}\text { Micro: human } \\
\text { agency/behavioral }\end{array}$ & Individuals representing agencies & Behavior/choice & $\begin{array}{l}\text { MAST, collaborative dynamics/measures } \\
\text { of program success }\end{array}$ \\
\hline $\begin{array}{l}\text { Meso: governance } \\
\text { considerations }\end{array}$ & Government_civil society & $\begin{array}{l}\text { Governance: state-societal } \\
\text { relations }\end{array}$ & $\begin{array}{l}\text { Institutional arrangements, policy } \\
\text { network, instrument choice }\end{array}$ \\
\hline Macro: systemic & $\begin{array}{l}\text { Environment } \\
\text { (landscape level problems) }\end{array}$ & $\begin{array}{l}\text { Resources/constraints/ } \\
\text { feedback }\end{array}$ & Problem definition \\
\hline
\end{tabular}

the relative importance of specific factors and arrangements in forest governance.

Second, focusing on the mesolevel, we argue that MAST represents a "new governance" arrangement. Recently, Tollefson et al. [3] and Howlett et al. [4] developed threedimensional frameworks in order to determine if there had been shifts from government to new governance arrangements in US and Canadian natural resource sectors. Tollefson et al.'s [3] framework is employed here to examine the three dimensions of new governance (institutional, political, and regulatory) in the case of MAST. Contrary to the other case study applications in the natural resource sector, we argue that MAST represents a new governance arrangement. We apply indicators of new governance related to institutional, political, and regulatory dimensions to illustrate how MAST represents a new governance arrangement defined by an interagency collaborative response to an unprecedented forest crisis.

\section{New Forest Governance Arrangements and the Necessity of Interagency Collaboration}

Moving away from a mode of coordination based on hierarchical top-down, command, and control management, governments have increasingly experimented with new modes of governance that rely on the incentives provided by markets or the sharing of information in governance networks. Due to complexities embedded in resource and environmental issues, environmental policy has been a key venue for governance changes. Recent advances in the natural resource governance literature have sought to capture these governance dynamics and their effects on policy making [4]. A large literature on contemporary governance arrangements suggests that nonstate actors have gained an increasingly important role in policy making as the complexity of policy problems has increased, a process of institutional change which governments have both reacted to and facilitated [5, 6]. Lacking the knowledge or the mandate to govern alone, governments have increasingly chosen to try to construct policy consensus through more engaged and interactive forms of policy making and to allow nonstate actors to implement those policies within a broad framework of incentives, benchmarking, and private governance [7]. This is true in many areas where efforts have been made to develop "integrated strategies" such as forestry and coastal marine ecosystem management [8] and similar efforts are typical in both climate change mitigation and adaptation efforts [9]. In these new governance modes, the lines between public and private have become blurred [10].

New governance arrangements call for increased attention towards the microlevel and novel collaborative efforts. In the microlevel, leadership, communication, and collaborative dynamics emerge. Collaborative management, engaging government agencies and departments with the general public, has been touted as a viable approach for addressing complex forest and natural resource management challenges $[11,12]$. In comparison, interagency collaborative efforts, involving multiple government agencies addressing natural resource management, have received far less attention. Most work on interagency collaboration has detailed how emerging partnerships have typically failed. Vangen and Huxham [13] found that "reports of unmitigated success are not common." Huxham [14] argues that "unless the potential for real collaborative advantage is clear, it is generally best if there is any choice to avoid collaboration." However, decision makers are increasingly recognizing that many natural resource issues cannot be adequately addressed in the absence of effective interagency collaboration. Additionally, dynamics of collaborative efforts and their relative success need to be understood in a larger governance context.

Understanding the role that mesolevel variables play in the governance of complex forest problems involves three specific dimensions: institutional, political, and regulatory. The first dimension is linked to the structure and pervasiveness of policy networks which address the balance of power between state actors and the societal actors and networks, which in turn are linked to the kinds of policy instruments that are chosen to give effect to new governance arrangements [15]. In this network dimension, the number and diversity of actors (state and nonstate) that exert some degree of power or influence over the outputs of the governance arrangements is a key facet of policy making [16]. In this respect, the concern of the analyst is to identify where political power lies in relation to society and the state $[17,18]$. The challenge is to determine whether, and to what extent, in specific sectors and issue areas the state or its agents are directly dictating the outcomes that emerge from the governance arrangement, more loosely "steering" the arrangement, or alternatively whether ultimate power to determine outcomes rests with nonstate actors (e.g., corporations, unions, and environmental civil society organizations) [19].

The second dimension has to do with the rigidity of institutional policy-related arrangements, namely, their formal or informal nature. The institutional aspects of governance arrangement can be assessed in terms of factors such as 
precision (how closely it constrains private action); obligation (the "bindingness" of its commands); and delegation (the extent to which the power to adjudicate and enforce these obligations is retained by a regulator or delegated to an independent third party) [3]. Recently, Doelle et al. [20] explored these two dimensions in a study of climate-change-based forest governance arrangements in Canada, New Zealand, and USA.

Finally, the third dimension, the policy process, illustrates the dynamic features of governance arrangements by focusing on policy making and policy change. The policy cycle [4] and policy change frameworks (e.g., advocacy coalition framework, institutional rational choice, and structural choice) [21-24] are familiar approaches that draw upon the network and institutional dimensions and provide an even finer, more empirical lens to understand the complexity and challenges of governance. Stedman [25] utilized these approaches in their examination of climate change adaptation policy formulation in the Canadian agriculture, forestry, and water sectors.

In this paper, we also evaluate what interagency collaboration entails and what factors make it successful. Bardach [26] argues that collaboration encompasses "activities by agencies intended to increase public value by having the agencies working together rather than separately." Similarly, Thomas [27] argues that collaboration is "an unmandated effort by public officials in at least two local, state, or federal agencies to coordinate their activities or share resources." This latter definition highlights the important point that interagency collaboration often arises not from an official mandate but through a shared recognition of a need by the parties involved. Whether parties collaborate, however, depends on many factors, including the extent to which they depend on one another [27]. Empirical studies suggest successful interagency collaborative efforts that include allowing participants to have flexibility, motivating lower level staff, providing accountability, ensuring quality, adequately addressing financial matters, identifying common aims, and maintaining purpose over time $[14,26,28,29]$. The interagency collaboration literature highlights three key indicators critical to interagency collaborative success: effective leadership, trust, and minimizing turf disputes (i.e., [13, $30-$ 32]). These three indicators represent key components of interagency collaboration.

Applying a three-level approach, we now focus on MAST and its response to an unprecedented forest crisis. The bark beetle outbreak and subsequent fires in the SBNF occurred at a macrolevel. Addressing this problem initiated efforts at the mesolevel (new governance arrangements in the institutional, political, and regulatory dimensions) and microlevel (interagency collaboration) to address it. Rather than focusing on the macrolevel and a top-down approach, this case affords the opportunity to look at how bottom-up interagency collaboration and new governance arrangements coalesced to address this challenge. In addition, this paper focuses attention on the interagency collaborative effort that emerged and the extent to which it addressed the three key indicators (leadership, trust, and minimizing turf disputes) necessary for effective collaboration put forth in the literature.

\section{Methods}

This project began by visiting forest systems experiencing unprecedented bark beetle outbreaks and forest health crises. Site visits occurred in New Mexico, Colorado, Wyoming, and British Columbia, and also included interviews with forest managers in Montana, Idaho, Washington, and Oregon. We selected the SBNF because it was experiencing an unprecedented forest dieback, had initiated significant management responses, had changed public policy, had received significant state and federal resources to address the situation, and also created a unique, interagency collaborative response to orchestrate and facilitate actions. These features set it apart from responses initiated elsewhere. After selecting this case, we implemented a mixed method approach for data collection and analysis. This included conducting 80 inperson key informant interviews with individuals associated with MAST over a two-year period. Interviews primarily focused attention on individuals directly involved in MAST (US Forest Service, CalFire, San Bernardino County representatives, California State agencies, the Natural Resource Conservation Service, local fire departments, and private companies) but also included elected officials, academics, and concerned citizens engaged in responding to the forest health crisis.

We developed and employed a semistructure interview guide that focused its attention on the causes and responses to the bark beetle outbreak, specifically how MAST organized and operated. The semistructure interview guide allowed for each interview to engage the unique perspective and expertise of each respondent. Interviews were recorded, transcribed, and analyzed using a coding system. In addition to interviews, observations were made at regional meetings related to MAST activities, as well as community group meetings that dealt with new regulations and fire protection plans. Finally, primary documents from government agencies and financial records related to MAST were collected and analyzed.

\section{Background: The San Bernardino National Forest}

The SBNF encompasses over 273,837 hectares of public land and three ranger districts [33] in southern California (Figure 1). The national forest resides within San Bernardino and Riverside Counties and lies just outside of the city limits of the city of San Bernardino. Chaparral, oak, piñon/juniper, and scrub ecosystems dominate the national forest but also include forests that harbor Coulter (Pinus coulteri), Ponderosa (Pinus ponderosa), Lodgepole (Pinus contorta), sugar (Pinus lambertiana), and Jeffrey (Pinus jeffreyi) pines, incense cedar (Calocedrus decurrens), canyon oak (Quercus chrysolepis), and Douglas fir (Pseudotsuga menziesii). Unlike most national forests that have contiguous public lands, the SBNF surrounds private property and towns with significant population centers. This creates difficult challenges for public land management, including the necessity to prioritize actions that protect private property. A USFS district ranger noted: "the SBNF has more people living within its 


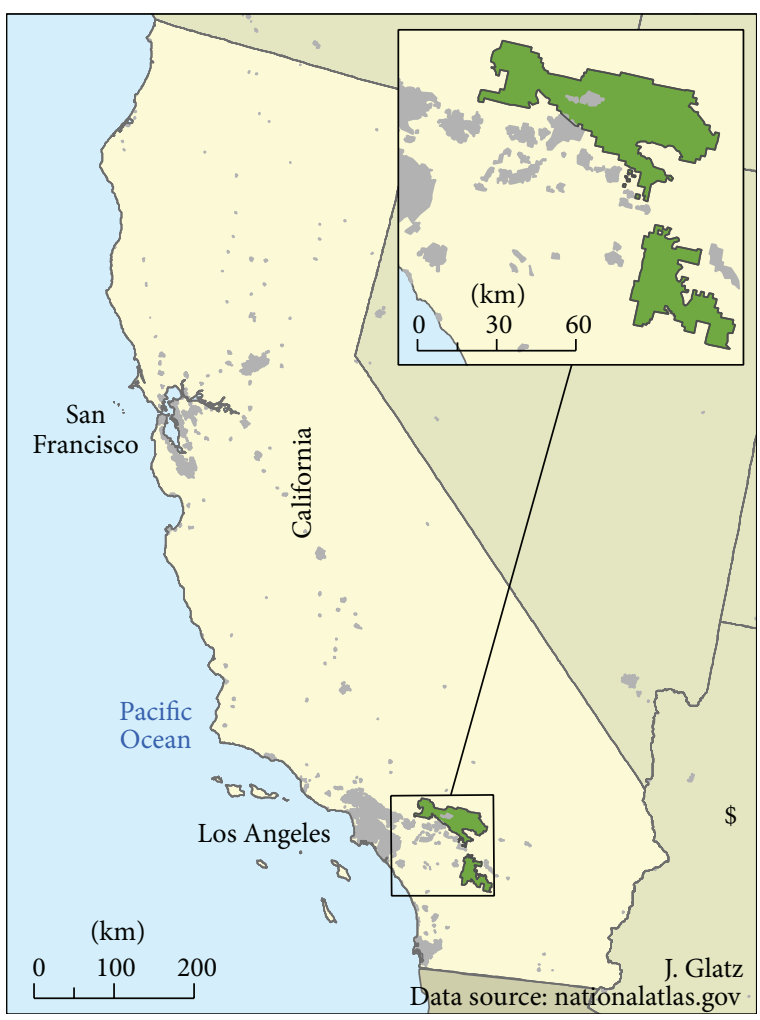

Figure 1: The San Bernardino National Forest.

boundaries than any other forest in the country." Private property in-holdings exceed 59,549 hectares on the forest [33]. Its proximity also makes the SBNF one of the most heavily visited national forests.

In recent decades visitors and residents demanded new USFS management practices that favored aesthetic values and recreation over timber production. Timber harvesting disappeared from the region by the mid-1970s. Without timber management, funds for providing aesthetic and recreation values diminished. Over time, the USFS dramatically changed its workforce: by the early 1990s the forest had no foresters on staff. This made it difficult to conduct any forest management operations, such as thinning projects. The latest forest plan explicitly states, "Lands with a timber management objective are not suitable on southern California national forests. These national forests need to be actively managed for a variety of other purposes, including wildlife habitat and recreation opportunities" [34].

4.1. Macro Level: Unprecedented Forest Health Crisis in the $S B N F$. The emergence of an unprecedented forest health crisis in the SBNF can be traced to the simultaneous interaction of three interrelated natural phenomena (bark beetle, drought, and catastrophic fires) and a legacy of forest management (Table 2). Depending on forest conditions, the Western Pine beetle (Dendroctonus brevicomis) fluctuates in population size. Across North America, bark beetles have caused unprecedented forest disturbances [35]. These outbreaks have occurred in forests dominated by conifer species. Outbreaks interact with other forest disturbances [36] and affect fire regimes [37]. They have recently affected high elevation stands formerly buffered by cold temperatures [38] and have had considerable economic as well as ecological consequences $[39,40]$. The SBNF bark beetle outbreak rapidly expanded beginning in 2000, and by 2002 represented a significant forest health crisis that policy makers and land managers had to respond to. By early 2003 70,000 hectares of the SBNF were affected ([41], cited in [1]).

Two major factors contributed to the unprecedented beetle outbreak: drought and fire suppression in the SBNF. Forest health acts as the primary control on beetle populations, as individual tree vigor is the primary defense against beetle outbreaks. Healthy trees have the ability to drive out beetles with resin [42], whereas drought and competition can reduce vigor, leaving trees more susceptible to attack. In the late 1990s a severe drought occurred across southern California. According to an ecologist working in the region, by the late 1990s, the SBNF forest landscape was in the "driest physical state it had been in since the 18th century."

Exacerbating the situation was a long history of fire suppression by government agencies. Past forest management contributed to a higher proportion of mature pine trees on the landscape and higher tree density levels [43]. Beetles preferentially attack mature pine trees and higher density levels increase tree competition for limited water and nutrients. We now turn to the meso- and microlevels to explore how MAST addressed this macrolevel crisis.

4.2. Mesolevel: The Mountain Area Safety Taskforce: A New Governance Arrangement. The threat of catastrophic fire and widespread tree mortality posed a significant risk to communities. The USFS in conjunction with a variety of other state and municipal agencies began discussions in November 2002 about addressing declining forest health. Preliminary meetings focused on finding ways to more efficiently address bark beetle and fire potential by cutting more trees and making communities less vulnerable to catastrophic fire. Collectively, there was a realization that no single agency could deal with such a complex problem. MAST, a coalition that included county, state, federal natural resource agencies, electric power companies, forest management contractors, and public safety agencies (Table 3), identified the following broad goals:

to develop and implement an integrated and coordinated approach to address the disaster's immediate impacts on life, safety, and social and economic values, while implementing a long-range recovery plan resulting in safe communities and ecological sustainability.

Based on Tollefson et al.s [3] three government to governance dimensions (institutional, political, and regulatory) we discuss MAST's organization and actions.

4.2.1. Formal but Voluntary: MAST's Institutional Dimensions. The nature of emergency management requires some degree of organization and formality. MAST efforts revealed strong 
TABle 2: Primary contributing factors leading to forest disturbances in the San Bernardino National Forest.

\begin{tabular}{lll}
\hline $\begin{array}{l}\text { Contributing factor to } \\
\text { forest disturbance }\end{array}$ & Context & Consequence \\
\hline Drought & $\begin{array}{l}\text { Driest physical state forests had been in over a } \\
\text { century. }\end{array}$ & $\begin{array}{l}\text { Trees died from water stress; those that survived } \\
\text { had increased vulnerability to bark beetles. }\end{array}$ \\
\hline $\begin{array}{l}\text { Forest management } \\
\text { practices }\end{array}$ & $\begin{array}{l}\text { Shift from forest cutting to forest protection; } \\
\text { managing for "park like" conditions; } \\
\text { homeowner laws and public perceptions that } \\
\text { limited or forbid direct forest management. }\end{array}$ & $\begin{array}{l}\text { Tree densities increased, as did the age class of trees, } \\
\text { contributing to a landscape with more mature trees, } \\
\text { which bark beetles preferentially target, providing } \\
\text { sufficient host material for the outbreak to occur. }\end{array}$ \\
\hline Fires & $\begin{array}{l}\text { Strict fire prevention practices and policies } \\
\text { implemented; removal of natural fire regime } \\
\text { across the landscape. }\end{array}$ & $\begin{array}{l}\text { Lack of fire contributed to dense forests with older } \\
\text { age classes. This created a continuous canopy that } \\
\text { contributed to uncontrollable crown fires. }\end{array}$ \\
\hline Beetles & $\begin{array}{l}\text { Endemic beetle populations had access to } \\
\text { increased host material due to drought and } \\
\text { more mature trees on the landscape. }\end{array}$ & $\begin{array}{l}\text { Controls that typically hold populations at low } \\
\text { levels were lost. Populations exploded, killing trees } \\
\text { at unprecedented levels. }\end{array}$ \\
\hline
\end{tabular}

TABLE 3: MAST member organizations.

\begin{tabular}{|c|c|}
\hline $\begin{array}{l}\text { Federal } \\
\text { partners }\end{array}$ & $\begin{array}{l}\text { US Forest Service } \\
\text { Natural Resources Conservation Service }\end{array}$ \\
\hline $\begin{array}{l}\text { State } \\
\text { partners }\end{array}$ & $\begin{array}{l}\text { California Department of Forestry and Fire } \\
\text { Protection (CalFire) } \\
\text { California Department of Transportation } \\
\text { California Highway Patrol }\end{array}$ \\
\hline $\begin{array}{l}\text { County } \\
\text { partners }\end{array}$ & $\begin{array}{l}\text { County of San Bernardino } \\
\text { San Bernardino County Fire Department } \\
\text { San Bernardino Office of Emergency } \\
\text { Services } \\
\text { San Bernardino County Department of Public } \\
\text { Works } \\
\text { San Bernardino County Sheriff } \\
\text { San Bernardino County Solid Waste Management } \\
\text { San Bernardino County Public Works/Hazardous } \\
\text { Tree Removal }\end{array}$ \\
\hline $\begin{array}{l}\text { Local fire } \\
\text { departments }\end{array}$ & $\begin{array}{l}\text { Arrowbear Lake Fire Department } \\
\text { Big Bear City Fire Department } \\
\text { Big Bear Lake Fire Protection District } \\
\text { Crest Forest Fire Protection District } \\
\text { Running Springs Fire Department } \\
\end{array}$ \\
\hline $\begin{array}{l}\text { Fire safe } \\
\text { councils }\end{array}$ & $\begin{array}{l}\text { Inland Empire Fire Safe Alliance } \\
\text { Angelus Oaks Fire Safe Council } \\
\text { Arrowhead Communities Fire Safe Council } \\
\text { Big Bear Valley Fire Safe Council } \\
\text { Lytle Creek Fire Safe Council } \\
\text { Mill Creek Canyon Fire Safe Council } \\
\text { Mountain Rim Fire Safe Council } \\
\text { Wrightwood Fire Safe Council }\end{array}$ \\
\hline $\begin{array}{l}\text { Public } \\
\text { utilities } \\
\end{array}$ & $\begin{array}{l}\text { Southern California Edison } \\
\text { Bear Valley Electric Company }\end{array}$ \\
\hline
\end{tabular}

institutional dimensions. Table 4 lists important institutional indicators of new governance and how these indicators can be identified in terms of the MAST organization. These indicators relate to inclusive planning, an informal mandate and an inclusive consultation process. Initially, MAST adopted a degree of formality in its institutional arrangements. After the initial meetings, MAST created a voluntary-based structure that included a core group, a unified command group, a media relations group, a liaison group to the broader community, and four sections that formed the base of the day-to-day organization: operations, planning, logistics, and financial management. According to participants, this organizational approach addressed critical barriers to implementing actions, setting priorities, and generally shaping the organizational structure and direction.

Compared to other collaborative efforts, MAST adopted a more informal horizontal organization arrangement. This was critical for utilizing resources. There was no formal agreement binding participating agencies to the effort and external funding that came from state and federal government agencies, including \$70 million through the Natural Resource Conservation Service. Despite government-wide budgetary cuts and diminished external funding, a decade later, MAST continues to operate in this manner. Interview respondents stated that MAST exceeded their initial expectations and critical land management actions were carried out in light of the catastrophic natural events. One person reflected a sense of optimism about the process: "It was amazing what we were able to do here. Absolutely amazing." Another said "I spent 40 years with the Forest Service, I have never seen a program run so effectively. It is probably, as far as I am concerned, the best example of how all levels of government can work together."

4.2.2. Shared Informal Decision Making: MAST's Political Dimensions. Interagency collaboration, as described above, has been proven to be difficult to achieve. Agencies defending turf or prioritizing their own as opposed to collective goals can derail interagency collaboration. MAST averted this problem in part due to their informal decision making process; Table 5 identifies the political indicators of new governance and highlights how they relate to MAST. Rather than create a top-down decision-making process that directed activities, MAST created an informal partnership. No organization had to formally join MAST and decision making, based on a gap analysis (see below), leveraged agency actions by allowing each agency to contribute in a way that protected their own interests but also contributed to the overall goals MAST established. Open meetings where partner organizations could contribute to discussions about 
TABLE 4: MAST's institutional dimension.

\begin{tabular}{ll}
\hline Institutional indicators & MAST \\
$\begin{array}{l}\text { Quantity and diversity of actors engaged in } \\
\text { the institutionalized process in question }\end{array}$ & $\begin{array}{l}\text { The most inclusive forest planning process in the region, MAST involved a } \\
\text { comprehensive set of public and private interests in the decision-making } \\
\text { process. }\end{array}$ \\
\hline Origin and nature of mandate & $\begin{array}{l}\text { Informal mandate agreed upon by diverse actors in response to looming } \\
\text { forest catastrophe. }\end{array}$ \\
$\begin{array}{l}\text { Nature and extent of consultation with } \\
\text { affected interests }\end{array}$ & $\begin{array}{l}\text { Created inclusive polycentric working group tasked with implementing } \\
\text { shared goals and objectives. }\end{array}$ \\
\hline
\end{tabular}

TABLE 5: MAST's political dimension.

\begin{tabular}{ll}
\hline Political indicators & MAST \\
\hline $\begin{array}{l}\text { Quantity and diversity of actors with some degree } \\
\text { of power or influence over decision/output }\end{array}$ & $\begin{array}{l}\text { Rather than a top-down, hierarchy, MAST enabled all interested } \\
\text { parties to contribute to decision making in collaborative fashion. }\end{array}$ \\
\hline $\begin{array}{l}\text { Actual formal decision-making power/actual not } \\
\text { formal ability to influence decisions and outcomes }\end{array}$ & $\begin{array}{l}\text { MAST partners collectively informally influenced decisions that } \\
\text { led to interagency actions by participating groups and entities. }\end{array}$ \\
\hline
\end{tabular}

objectives and actions facilitated communication and shared decision making. MAST decisions enabled each partner organization to contribute based on their missions and abilities, while still making important contributions to established MAST priorities. MAST established a framework that enabled dialogue between partner organizations that had not occurred previously in the region. Interview respondents that participated in MAST suggested that the communication and joint decision making were the primary factors that enabled MAST to effectively organize a response to the forest health crisis.

4.2.3. Setting Priorities: MAST's Regulatory Dimension. Table 6 illustrates how MAST demonstrates regulatory indicators of new governance. MAST followed the "soft law" process. In a soft law process there is no formal entity with jurisdiction to institute or demand hard law outcomes and partners that contribute to decisions. MAST participants had no formal commitment, participating as equal partners with shared goals. It was organized in a way that gave voice to all participants. Rather than agencies and stakeholders working to meet their own objectives, MAST created a platform to allow an integrated response that focused on the forest system, not political boundaries. Actions taken thus dealt with pressing problems on federal, state, county, and private lands. MAST helped orchestrate policy changes at the state and county levels, as well as policies regulating vegetation management on private lands that facilitated their agreed upon objectives. Through this process, MAST garnered legitimacy both in a regulatory sense and also in terms of public perception. That legitimacy then enabled MAST to set priorities and implement actions.

MAST established three priorities early on that helped direct their efforts to effectively address the beetle outbreak and forest health crisis. First, they sought to protect communication sites such as radio towers and radio repeaters vital for ensuring effective communication during an emergency across the SBNF. In particular, these would help communication efforts in the case of evacuating all residents living in or near the SBNF. MAST identified those sites that needed protection and designed fuel treatments in the surrounding forest areas to divert fire away from them. Protecting evacuation corridors and putting in place an evacuation plan was MAST's second major activity. Only a few roads access the many mountain communities, housing developments, and individual houses in the SBNF. Trees falling over roads or fires hinder emergency evacuation and could also inhibit emergency services and firefighters from accessing communities in need. MAST identified key corridors needing tree thinning to ensure that blockages would not occur. Finally MAST set out a broad strategy of community protection. MAST identified those areas most in danger from fires and worked across agencies to put in place plans to remove dead trees near homes and undertake long-term fuel reduction projects on community edges in an attempt to lower the likelihood of fire and to divert fires away from communities. Such projects created breaks in forest canopies and fuel breaks to divert fires around communities and attempted to foster long-term efforts to ensure that forest regrowth would not recreate similar conditions conducive to another bark beetle outbreak.

The actions MAST took required a new regulatory framework. Previous to the bark beetle outbreak, agencies and institutions with jurisdiction over land management in and around the SBNF did not, and in many cases could not, effectively work in an integrated fashion. MAST created a voluntary organization that, coupled with policy changes, established an interagency collaborative framework to collectively take action. This hybrid system, including agencies and stakeholders working to meet their own objectives while simultaneously working to meet the broader goals established by MAST, enabled effective forest management to occur. MAST successfully implemented management actions that many respondents indicated had not occurred for decades and were long overdue.

\subsection{Microlevel: Interagency Collaboration: The Nuts and Bolts of New Governance Arrangements. MAST faced}


TABLE 6: MAST's regulatory dimension.

Regulatory indicators
Quantity and diversity of actors engaged in
the regulatory arrangement

Precision (how closely does the output prescribe and constrain private action?)

Obligation (how legally binding is the obligation?)

Delegation (is the duty of adjudicating and enforcing the obligation vested in an independent third party or retained by the regulator?)
MAST

Formal and informal partners contributed to regulatory arrangement. Decisions followed a soft law process in which partners contributed to decisions (i.e., no formal entity had jurisdiction to institute or demand hard law outcomes).

Precision: the decisions made had direct implications for federal, state, and county agencies, as well as private landowners (i.e., the decisions affected land of all types of land jurisdictions).

Obligation: policy changes at the state level as well as changes to county and property laws facilitated legally binding actions regarding forest and property management that did not exist prior to the outbreak.

Delegation: Policy changes provided delegation of enforcement to MAST partners, supported by the public legal system. multiple on-the-ground obstacles not readily observed in the mesolevel new governance literature. Successful interagency collaboration requires a continual contribution of its voluntary participants who support the efforts' objectives while balancing their own agency's goals. This proves particularly important when confronting unprecedented, landscape level problems where effectiveness requires innovation and flexibility, working effectively across both internal and external agency boundaries, moving away from short-term goals, and recognizing the need to maintain a long-term focus.

Within this unique new governance arrangement, there were a number of specific on-the-ground features that helped MAST successfully meet stated goals and objectives. These features cannot be captured in the mesolevel literature. Evaluating whether a program or effort is successful when faced with everyday problems can prove challenging. Challenges on the scale on the SBNF posed even greater obstacles. However, interview participants highlighted two primary indicators for program success: meeting short-term goals and facilitating long-term fuel modification work. The 2003 fires burned 60,700 hectares and destroyed over 1,000 structures [44]. The thinning work and tree removal efforts spared all the communication sites in the SBNF, thus allowing for communication to continue unimpeded. Uninterrupted communication was important for meeting the second shortterm goal, implementing a resident evacuation strategy.

Interview respondents deemed evacuation efforts a success because law enforcement partners held public meetings, distributed materials, and used public service announcements to educate the public about the evacuation strategy. After the fires started, MAST partners initiated the evacuation plan. The County Sheriff Department brought in deputies along with search and rescue volunteers to provide residents with evacuation instructions and procedures. They used loudspeakers in neighborhoods to inform residents, implemented an emergency telephone system, and used helicopters to assess the situation and identify residents in need. On the roadways, established plans directed residents to evacuation routes and the county and state law enforcement agencies worked together to maintain order over the two days in which over 45,000 people were successfully evacuated [44].

The third and longer-range MAST objective was to reduce community vulnerability to fire through fuel modification work. Several fires, including the Grass Valley Fire in 2007 burned 199 homes. However, fuel modification efforts prevented more damage. In particular, an analysis of fire behavior showed that fuel modification efforts have decreased the intensity of fires and in several cases diverted fires around homes and communities [45]. A county fire marshal noted that "a \$60,000 fuel break saved over 500 homes."

Promoting community fire safety occurred at three different levels. First, individual homeowners could apply for the federal Forest Care Program that funded the removal vegetation around homes. Homeowners who do not meet county ordinance requirements were still eligible for $75 \%$ reimbursement for fuel reduction work coordinated through Forest Care. According to a coordinator of the Forest Care program, 1275 homeowners utilized the program, treating over 265 hectares. Second, at the county level, the San Bernardino Hazard Tree Program undertook fuel modification work. The program treated over 15,059 hectares and removed over 300,000 trees in and around SBNF communities. And finally, the USFS also undertook fuel modification work throughout SBNF. According to a USFS regional forest manager, between 2003 and 2010 fuels reduction work on nearly 30,000 hectares was undertaken, representing approximately $11 \%$ of the SBNF's land base.

4.3.1. Factors Contributing to Interagency Success. The literature on interagency collaboration highlights the importance of leadership in promoting successful outcomes $[13,14,26$, $28-30,46]$. The SBNF forest supervisor provided strong leadership in initiating MAST's formation. As a result, other agencies contributed resources and personnel to the effort. The group of agency heads that directed the high level policy discussions for MAST established priority actions and goals 
that subgroups utilized to identify on the ground activities necessary to meet the broader MAST goals.

In addition to individual and organizational leadership within MAST, its partner organizations and individuals within those agencies illustrated key leadership regarding public relations. The MAST organization established threats and priorities that all participants agreed upon. This shared perspective created cohesiveness among those involved and more importantly a shared understanding of both the problems they collectively faced and the solutions to them. This unanimity allowed each person involved in MAST to serve as a spokesperson to clearly convey the approach MAST had undertaken to address the threats facing communities and homeowners across the mountain. MAST members held public meetings across mountain communities and talked about the role their particular agency played in the effort but also had the ability to speak competently about the broader MAST effort. This enabled MAST representatives to effectively communicate with the public to generate support for forest management actions that prior to the outbreak would not have found support. This played an important role in moving MAST objectives forward.

The interagency collaboration literature often raises the importance of participants having common aims. The impending and ongoing natural disasters in the SBNF contributed to a coherent aim across MAST organizations. Many individuals found that MAST shaped participant perceptions. As a respondent from CalFire put it "the experience of MAST caused the participants to view their own particular problem in relationship to how it impacted all the other agencies" and "that is probably the most unique factor out of MAST, the shaping of perceptions."

Turf issues and trust represent the other two primary issues affecting interagency collaborative efforts. In this case, the shared perception of an imminent threat to life and property brought entities with jurisdiction on the mountain together to address a common problem and facilitated trust and a shared understanding across MAST members. The creation of MAST helped galvanize trust and a common purpose across partner organizations. This led to partner organizations and individuals within them contributing without worrying about turf battles or seeking credit or attention.

Undertaking an institutional gap analysis represents one of MASTs most innovative and important elements. Respondents suggested that the gap analysis emerged during their efforts to identify how many partner organizations had jurisdiction across the mountain and to identify their mandates. From that baseline they then identified specific actions each entity could take and from that collective assessment identified what actions remained unaddressed. This process served to streamline action and reduce turf battles. MAST set out in early 2003 to undertake a gap analysis of all the entities with jurisdiction over land management or communities. The gap analysis identified the partner organizations, their responsibilities, and assessed whether they could meet their responsibilities given the forest health crisis. It also provided a means to identifying how partners could combine their efforts to expedite tree removal and fuel management projects. Without a gap analysis each partner would have continued to engage in efforts isolated from those taken by others. The gap analysis allowed both streamlining work and leveraging the actions of each partner to more strategically address broader MAST goals.

\section{Conclusion}

The bark beetle outbreak that erupted in the SBNF not only posed a significant threat to community safety but also rendered existing governance impotent to address an unprecedented landscape level problem. Occurring at a macrolevel, this forest health emergency necessitated a mesolevel response that included specific actions at the microlevel. The MAST emerged to meet the challenges posed. Dense housing in overstocked forests susceptible to catastrophic fire created a dangerous situation that compelled agencies to respond. The recognition that individual agencies could not alone address the issue necessitated a collaborative response. MAST formed expressly to maximize collective resources and work across agencies to initiate projects that reduce the threat fire posed to communities.

The literature on new governance highlights elements that differentiate MAST from traditional or "old" governance approaches. These include governance arrangements that blur the lines between private and public interests. As illustrated by institutional, political, and regulatory indicators, we argue that MAST represents an example of new governance. MAST strategically incorporated private actors in its decision making and more importantly in its on-the-ground actions. This included energy companies that had jurisdiction over power lines on the mountain, private contractors to undertake forest thinning projects, and individual property owners engaged in vegetation thinning across private property. More importantly, MAST embodied a new governance approach by introducing a flexible policy approach that engaged a large diversity of actors. MAST had a strategic, hierarchical planning process that enabled all actors to participate and inform decision making. No one agency had supremacy over others and each agency committed to following the process and decision made collectively by MAST. This organizational structure served to engage all actors, provide them a reason to participate, and has created a lasting governing structure that met short-term objectives and persists to address decadeslong objectives related to maintaining forest health across the landscape.

MAST created an effective interagency collaborative effort. Particular elements contributed to this outcome. The literature on interagency collaboration singles out leadership, trust, and minimizing turf disputes as critical to effective interagency collaboration. MAST created a new governance structure that addressed these three elements. A gap analysis identified who could contribute and where vulnerabilities existed across agencies. In addition to those elements, other factors fell into place that enabled work to move forward. MAST helped coordinate an effort that led to effective measures to reduce the risk of fire to communities, protect communication towers, and the successful evacuation of residents threatened by fire. In some cases, analyses of 
fire behavior have shown that fuel modification work has successfully diverted fires away from communities.

Through the creation of a new governance arrangement to address forest health problems in Southern California, MAST has established a model that others can manipulate to address macrolevel problems through meso- and microlevel responses. Interagency collaboration will undoubtedly play a prominent role in addressing landscape level forest problems in the future elsewhere and MAST provides insights on how to create such an approach.

\section{Conflict of Interests}

The authors declare that there is no conflict of interests regarding the publication of this paper.

\section{References}

[1] M. L. Bond, D. E. Lee, C. M. Bradley, and C. T. Hanson, "Influence of pre-fire tree mortality on fire severity in conifer forests of the San Bernardino Mountains, California," The Open Forest Science Journal, vol. 2, pp. 41-47, 2009.

[2] A. E. Dunn, A. Gonzalez-Caban, and K. Solari, The Old, Grand Prix, and Padua Wildfires: How Much Did These Fires Really Cost? USDA Forest Service, Riverside, Calif, USA, 2005.

[3] C. Tollefson, A. R. Zito, and F. Gale, "Symposium overview: conceptualizing new governance arrangements," Public Administration, vol. 90, no. 1, pp. 3-18, 2012.

[4] M. Howlett, J. Rayner, and C. Tollefson, "From government to governance in forest planning? Lessons from the case of the British Columbia Great Bear Rainforest initiative," Forest Policy and Economics, vol. 11, no. 5-6, pp. 383-391, 2009.

[5] O. E. Williamson, The Economic Institutions of Capitalism: Firms, Markets, Relational Contracting, Free Press, New York, NY, USA, 1985.

[6] R. A. W. Rhodes, "The new governance: governing without government," Political Studies, vol. 44, no. 4, pp. 652-667, 1996.

[7] D. Sprinz and T. Vaahtoranta, "The interest-based explanation of international environmental policy," International Organization, vol. 48, no. 1, pp. 77-105, 1994.

[8] M. Howlett and J. Rayner, "Globalization and governance capacity: explaining divergence in national forest programs as instances of "next-generation" regulation in Canada and Europe," Governance, vol. 19, no. 2, pp. 251-275, 2006.

[9] J. Voss, D. Bauknecht, and R. Kemp, Eds., Reflexive Governance for Sustainable Development, Edward Elgar, Cheltenham, UK, 2006.

[10] A. Gatto, "The law and governance debate in the European Union," Discussion Paper, International Institute for Labour Studies, Geneva, Switzerland, 2006.

[11] J. M. Wondolleck and S. L. Yaffee, Making Collaboration Work: Lessons from Innovation in Natural Resource Management, Island Press, Washington, DC, USA, 2000.

[12] M. Nie, The Governance of Western Public Lands: Mapping Its Present and Future, University of Kansas Press, Lawrence, Kan, USA, 2008.

[13] S. Vangen and C. Huxham, "Enacting leadership for collaborative advantage: dilemmas of ideology and pragmatism in the activities of partnership managers," British Journal of Management, vol. 14, pp. S61-S76, 2003.
[14] C. Huxham, “Theorizing collaboration practice," Public Management Review, vol. 5, pp. 401-423, 2003.

[15] M. Howlett, Designing Public Policies: Principles and Instruments, Routledge, New York, NY, USA, 2011.

[16] D. Knoke, Political Networks: The Structural Perspective, Cambridge University Press, Cambridge, Mass, USA, 1987.

[17] S. Lukes, Power: A Radical View, Macmillan, London, UK, 1974.

[18] C. E. Lindblom, The Policy-Making Process, Yale University Press, New Haven, Conn, USA, 1977.

[19] D. McCool, "The subsystem family of concepts: a critique and a proposal," Political Research Quarterly, vol. 51, no. 2, pp. 551-570, 1998.

[20] M. Doelle, C. Henschel, J. Smith, C. Tollefson, and A. Wellstead, "New governance arrangements at the intersection of climate change and forest policy: institutional, political and regulatory dimensions," Public Administration, vol. 90, no. 1, pp. 37-55, 2012.

[21] T. Moe, "The new economics of organization," Journal of American Political Science, vol. 28, pp. 739-777, 1984.

[22] E. Ostrom, "Rational choice and institutional analysis: towards a complementary," American Political Science Review, vol. 85, pp. 237-243, 1991.

[23] E. Schlager and W. Blomquist, "A comparison of three emerging theories of the policy process," Political Research Quarterly, vol. 49, no. 3, pp. 651-672, 1996.

[24] P. Sabatier and H. Jenkins-Smith, "The advocacy coalition framework: an assessment," in Theories of the Policy Process, $\mathrm{P}$. Sabatier, Ed., Westview, Boulder, Colo, USA, 1999.

[25] R. C. Stedman, "Risk and climate change: perceptions of key policy actors in Canada," Risk Analysis, vol. 24, no. 5, pp. 13951406, 2004.

[26] E. Bardach, Getting Agencies to Work Together: The Practice and Theory of Managerial Craftsmanship, Brookings Institution Press, Washington, DC, USA, 1998.

[27] C. W. Thomas, Bureaucratic Landscapes: Interagency Cooperation and the Preservation of Biodiversity, The MIT Press, Cambridge, Mass, USA, 2003.

[28] C. Huxham and S. Vangen, "Doing things collaboratively: realizing the advantage or succumbing to inertia?" IEEE Engineering Management Review, vol. 32, no. 4, pp. 11-20, 2004.

[29] S. Page, "Entrepreneurial strategies for managing interagency collaboration," Journal of Public Administration Research and Theory, vol. 13, no. 3, pp. 311-340, 2003.

[30] E. Bardach, "Developmental dynamics: interagency collaboration as an emergent phenomenon," Journal of Public Administration Research and Theory, vol. 11, no. 2, pp. 149-164, 2001.

[31] S. Vangen and C. Huxham, "Nurturing collaborative relations: building trust in interorganizational collaboration," Journal of Applied Behavioral Science, vol. 39, pp. 5-31, 2003.

[32] D. P. Moynihan, "The network governance of crisis response: case studies of incident command systems," Journal of Public Administration Research and Theory, vol. 19, no. 4, pp. 895-915, 2009.

[33] SBNF, San Bernardino National Forest, 2009, http://www.fs. fed.us/r5/sanbernardino/about/index.shtml.

[34] USFS. United States Forest Service, Final Environmental Impact Statement, Volume 1. Land Management Plans: Angeles National Forest, Cleveland National Forest, Los Padres National Forest, San Bernardino National Forest, R5-MB-074-A, USDA Forest Service, Pacific Southwest Region, 2005. 
[35] K. F. Raffa, B. H. Aukema, B. J. Bentz et al., "Cross-scale drivers of natural disturbances prone to anthropogenic amplification: the dynamics of bark beetle eruptions," BioScience, vol. 58, no. 6, pp. 501-517, 2008.

[36] C. D. Allen, "Interactions across spatial scales among forest dieback, fire, and erosion in northern New Mexico landscapes," Ecosystems, vol. 10, no. 5, pp. 797-808, 2007.

[37] M. J. Jenkins, E. Hebertson, W. Page, and C. A. Jorgensen, "Bark beetles, fuels, fires and implications for forest management in the Intermountain West," Forest Ecology and Management, vol. 254, no. 1, pp. 16-34, 2008.

[38] K. F. Raffa, E. N. Powell, and P. A. Townsend, “Temperaturedriven range expansion of an irruptive insect heightened by weakly coevolved plant defenses," Proceedings of the National Academy of Sciences of the United States of America, vol. 110, no. 6, pp. 2193-2198, 2013.

[39] M. N. Patriquin, A. M. Wellstead, and W. A. White, "Beetles, trees, and people: regional economic impact sensitivity and policy considerations related to the mountain pine beetle infestation in British Columbia, Canada," Forest Policy and Economics, vol. 9, no. 8, pp. 938-946, 2007.

[40] C. G. Flint, B. McFarlane, and M. Müller, "Human dimensions of forest disturbance by insects: an international synthesis," Environmental Management, vol. 43, no. 6, pp. 1174-1186, 2009.

[41] L. Merrill, "Bark beetles and tree mortality in the San Bernardino Mountains: current situation and outlook," Unpublished Report, USDA Forest Service, Region 5, Southern California Shared Service Area, San Bernardino, Calif, USA, 2003.

[42] N. E. Grulke, R. A. Minnich, T. Paine D et al., "Air pollution increases forest susceptibility to wildfires: a case study in the San Bernardino Mountains in southern California," in Developments in Environmental Science, Volume 8. Wildland Fires and Air Pollution, A. Bytnerowicz, M. J. Arbaugh, A. R. Riebau, and C. Andersen, Eds., pp. 365-403, Elsevier, Amsterdam, The Netherlands, 2009.

[43] R. A. Minnich, M. G. Barbour, J. H. Burk, and R. F. Fernau, "Sixty years of change in Californian conifer forests of the San Bernardino Mountains," Conservation Biology, vol. 9, no. 4, pp. 902-914, 1995.

[44] J. G. Taylor, S. C. Gillette, R. W. Hodgson et al., "Informing the network: improving communication with interface communities during wildland fire," Human Ecology Review, vol. 14, no. 2, pp. 198-211, 2007.

[45] G. Rogers, W. Hann, C. Martin, T. Nicolet, and M. Pence, "Fuel treatment effects on fire behavior, suppression effectiveness, and structure ignition. Grass valley fire, San Bernardino National Forest,” Tech. Rep. R5-TP-026a, USDA Forest Service, 2008.

[46] L. J. Johnson, D. Zorn, B. K. Y. Tam, M. Lamontagne, and S. A. Johnson, "Stakeholders views of factors that impact successful interagency collaboration," Exceptional Children, vol. 69, no. 2, pp. 195-209, 2003. 